\title{
ФОНЕТСКИ ДИЈАЛЕКТИЗМИ КАО ОБЕЛЕЖЈЕ КНИЖЕВНОУМЕТНИЧКОГ СТИЛА ВИОЛЕТЕ ЈОВИЋ У РОМАНУ ПРЕОБРАЖЕЊЕ
}

\begin{abstract}
Предмет овог рада јесте испитивање особина фонетских дијалектизама на примеру романа Преображеље Виолете Јовић са освртом на књижевноуметничке особености дела. Роман је написан на сврљишко-заплањском дијалекту, који је део призренско-тимочке дијалекатске области. Циљ овог рада биће анализа фонетских особина сврљишко-заплањског дијалекта. Такође, биће показано како је посредством дијалекта извршена карактеризација ликова и мотивација дела.

Кључне речи: српски језик, дијалектизми, сврљишко-заплањски дијалекат, призренско-тимочка дијалекатска област, роман, Преображење, Виолета Јовић.
\end{abstract}

\section{1. Увод}

Виолета Јовић својим делима пружа слику једног слоја друштва, његовог менталитета и српске патријархалне породице која чува изворе своје културе и традиције. Роман Преображење симболичан је наслов за причу о моралном и духовном преображају наивне сеоске девојке у одлучну жену која се храбро суочава са свим животним (не)приликама попут Михаиловићеве Петрије. Романескна радња смештена је у неименовано сврљишко село, што се да закључити само на основу неколико чињеница: 1) намера ауторке да у својим делима ослика људе из свога завичаја ${ }^{2}, 2$ ) говорне особине јунака романа, 3) помињање топонима Дервен ${ }^{3}$ као најближег већег места у околини. Време романескне радње такође није прецизирано, али се да претпоставити да је смештено у средину 20. века на основу појединих сегмената из дела (патријархална схватања описана у делу, сегменти где главна јунакиња описује актуелне модне трендове, текући догађаји попут прикључивања електричне енергије у селу и сл.)

\footnotetext{
${ }^{1}$ saranemat3@gmail.com

2 Под тим подразумевам село Мечји До.

${ }^{3}$ Варош у сврљишком округу.
} 
Радња романа прелама се кроз свест главне јунакиње Милице, која у исповедном монологу открива пут који је прешла до преображаја износећи у њему многе животне истине. Може се рећи да је ово роман о тражењу и проналажењу животне среће са поруком да се она налази тамо где је најмање очекујемо и да нам долази онда када јој се најмање надамо.

У овом раду ће се на примеру романа Преображење представити језик и књижевноуметнички стил књижевнице Виолете Јовић. О овим одликама књижевног стваралаштва до сада није писано у нашој књижевнотеоријској и лингвистичкој науци. Како бисмо приближили језик и стил ове наше књижевнице кренули смо од интервјуа са њом. Циљ нам је био да од самог уметника дознамо лични однос према сопственом стваралаштву, односно виђење свог књижевног приступа. Након овог првог дела рада приступили смо анализи језика романа. Одабрали смо специфичне фонетске одлике сврљишко-заплањског дијалекта којим је написан роман Преображење. Анализом језика којим се служи књижевница покушава се успоставити однос између књижевноуметничког приступа и самог језика дела полазећи од претпоставке да та веза представља узајамну условљеност.

\section{2. Виолета Јовић о своме стваралаштву и роману Преображење или уместо биографије писца ${ }^{4}$}

\section{- Шта Вас је навело да напишете роман Преображеюе?}

Волим обичног човека из народа, оног који живи свој живот далеко од светла свих позорница и јавности. Његов живот није ништа мање занимљив од живота свих до сада описаних и осликаних ликова. Напротив, мишљења сам да сваки живот заслужује пажњу, а да око нас има толико дивних и тешких, комичних и трагичних, компликованих, сложених и замршених и свакојаких других прича које заслужују да буду испричане.

Веома волим свој народ. Волим да разговарам са људима и слушам мелодију народног говора који тече и жубори као планински поток бистре воде из бистрих умова. Бојим се да нећу живети толико дуго, колики је ток тог потока, да могу да испричам све оне дивне приче које наш homo anonimus, да га тако назовем, казује сасвим чисто и природно, на народну... Али знам да ћу се читавог живота борити да се о том истом анонимном човеку, који је срж нашег националног бића, сазна што је могуће више. То је мотив писања свих мојих књига, а нарочито оних које су на народном говору.

\section{- Који је био Ваш примарни циљ приликом писања овог дела?}

Делимично сам на ово питање одговорила у претходном. Примарни циљ је увек чување језика завичаја. Али не само језика, већ и менталитета нашег човека.

\footnotetext{
${ }^{4}$ Интервју са писцем настао је искључиво за потребе писања овог рада.
} 


\section{- Због чега сте се одлучили за стваралаштво на дијалекту?}

Ex, родила сам се с тим опредељењем. Нека посебна одлука није ми била потребна. Дијалекат на коме пишем је мој матерњи језик. Само следим ону Вукову о томе да пишемо како говоримо. А ја тај језик говорим као матерњи, „књижевни стандард” учила сам у школи, малтене као страни језик. Најбоље мислим на матерњем језику и најбоље на њему умем да дочарам лепоту предела и људске душе, то је моја природна средина.

Рођена сам у Нишу, само из разлога што је требало да будем прво мушко дете у породици, након дугог ишчекивања потомка, из страха мојих родитеља да нешто не пође по злу. Моја породица одувек је живела у селу Мечји До, општина Сврљиг. Тамо живи моја мајка и тамо је једино место које истински могу назвати домом. Тамо је моје збринуто и срећно детињство задојено љубављу према коренима и људима који живе у складу са природом, природно се понашају и споразумевају језиком који је сасвим јасан и који сви разумеју. Говор Сврљига и његових села је аутохтон, и за мене најлепши језик, после песме птица и жубора потока.

Тим језиком се и даље говори у мом крају и ја, колико год да сам одсутна и макар ишла до краја света, кад пређем Грамаду у правцу Сврљига, аутоматски проговарам тим говором како се не бих разликовала од оних које сматрам и осећам својима. Можда сам и ја аутохтона врста, попут сврљишке овце, неких врста лековитих трава и свега оног по чему се мој родни крај препознаје као аутентичан? Само сам природни део њега. Није ме срамота да будем оно што јесам. Напротив, веома сам поносна због тога што јасно и прецизно знам ко сам.

\section{- Да ли у дијалекту видите посебну улогу и која је његова улога по Вашем мишљењу?}

Дијалект је обележје аутентичности. Део фолклора, културне ризнице коју имамо обавезу да баштинимо и чувамо као део нашег националног бића. То је наш корен.

Дијалект није непознавање сопственог језика, већ је његово богатство, „дукат на језику”, доказ колико је различитости и сличности у говорима где живи наш народ и колико лепоте је у томе. Он је основа споразумевања, али и толеранције, разумевања и сарадње, повезивања и трајања.

Да се ја питам, не бих у уста јунака књига, филмова и серија вештачки стављала језик који они, географски, никада нису говорили, већ бих пустила да свако говори својим идиомом и терала да разговарају и разумеју се. То је основа свих наших разумевања. Ако човека пажљиво слушаш и до краја ти буде јасно шта је заиста рекао, разумећеш његове одлуке и потребе и разлоге...

Дијалекат је говор наших предака, самим тим и наш и нико од нас нема права да га се одрекне. То је као да се одриче себе самога и жели да 
буде неко други. То није страна појава у нас. Али кидањем корена и жељом да се лелуја негде другде без стабилног ослонца у пореклу-корену, а нисмо ни птица ни лист на ветру, долазимо до тога да у коначном не знамо ко смо.

Дијалекат је веома важан за књижевност. Најпре, као језик комуникације међу људима који није измишљен из не знам којих потреба и виших или подлих разлога, већ је то језик као средство споразумевања између људи које траје вековима, од постанка једног народа, у њему свака реч има свој корен, као што и сваки човек има свој корен, зна се тачно шта означава и на који начин. Важан је не само за књижевно стваралаштво, већ и за теорију књижевности, за изучавање и научно сагледавање таквог језика, фонетски, али и историјски, социолошки... Ако је докторска дисертација помак у развоју научне мисли заснован на резултатима истраживања, замислите колико је поље истраживања у безграничном богатству дијалеката српскога језика!

- Како тумачите или доживљавате књижевну функцију дијалеката?

Мислим да је свако књижевно дело у коме су дијалози књижевних ликова дати на језику којим они не говоре вештачка творевина.

Ово може изазвати гомилу коментара стручњака и теоретичара и лектора, али, и после тих коментара људи ће наставити да говоре тако како се говори у одређеним подручјима, а ми ћемо, не желећи да знамо то, наставити да игноришемо дијалекат као реалност и бавићемо се помаком у развоју језика реакцентовањем речи којима ће спикерке у ТВ Дневнику ломити језик, а ми се смејати да не бисмо плакали. Но, да не идемо тако радикално, мислим да је функција дијалекта да дода оно боја и живота у књижевност колико их додаје сама природа. То се мора радити вешто и зналачки, јер није дијалекат псовка, улична фразеологија и извртање језика, само да би то засмејавало широке народне масе. Треба га истргнути из пејоративне употребе у говору и књижевности и те фине народне „вреве” дати у уста ономе ко ће њима умети да дочара песничке слике и стилске фигуре, да оне остану упамћене ва вјеки веков, као богатство и чиста лепота језика у књижевном делу.

\section{3. Призренско-тимочка дијалекатска област}

Роман Преображење, који је предмет наше анализе, написан је на сврљишко-заплањском дијалекту који је део призренско-тимочке дијалекатске области. Призренско-тимочка дијалекатска област простире се од Призрена на југу до реке Тимок на северу, а обухвата штокавске екавске говоре југоисточне Србије и дела Косова. Призренско-тимочких говора има и у долини Велике Мораве, у Шумадији и у околини Београда где се у 18. и 19. веку доселило становништво са поменутих простора, које још увек, потпуно или делимично, чува свој дијалекат. Међутим, поменуте границе не могу 
бити сасвим прецизне, с обзиром на то да у граничним подручјима дијалекатских зона увек има преплитања говорних особина (БОГДАНОВИЋ, МАРКОВИЋ 2000: 149).

Призренско-тимочки говори су се од 13. века одвојили од осталих штокавских говора са којима су до тада имали симултани развој. Они се најпре издвајају по извесном броју архаизама, али и низом иновација, пре свега балканистичког типа. У архаизме спадају: чување посебне фонеме за полугласник, чување вокалног $л$ и финалног $л$, док су најкарактеристичније иновације: губитак квантитативних разлика, претварање синтетичке деклинације у аналитичку, претварање синтетичке компарације у аналитичку, губитак инфинитива и употреба удвојених облика личних заменица (ИВИЋ 1985: 110).

Међутим, без обзира на утврђене заједничке одлике свих призренскотимочких говора, присутне су и извесне разлике између говорних типова овог дијалекта. С обзиром на то, Александар Белић ову област дели на три дијалекта: тимочко-лужнички, призренско-јужноморавски и сврљишкозаплањски.

Подручје сврљишко-заплањског дијалекта одликује се необичним обликом. То је трака дуга око 120 километара, а широка око 15 километара, која се протеже, помало кривудајући, преко многих долина и планинских масива, најчешће без природних граница. Једину константу чини однос према долини Јужне Мораве: подручје сврљишко-заплањског дијалекта постављено је паралелно са њеним током и то тако да нигде не силази у долину, али се нигде не удаљава много од ње (ИВИЋ 2009: 195).

Најважније одлике сврљишко-заплањског дијалекта су: чување финалног -л (бил, знал, ђавол, котьл); одсуство јотовања у композитима од ити (дојдем, најдем, пројдем); одсуство јотовања лабјала (гробје, снопје, здравје, али: зеље, трње, орање, пруће); чување групе дл (седла, падла); императив на -ете (носете, видете, рекнете), али и императив типа: јеђ, вић, поглеђ; непознавање палатализације оклузива у групама ке, ге, кu, ги (руке, ноге, ракија, други); $\hbar, \hbar$, а не ч, и у примерима типа: ноћ, кућа, веђа, међа; непознавање употребе члана; чување старог датива једнине на -y и -е (моему сину, брату, детету; наше сестре, жене, матере), а могућа је и појава датива множине на -м (женам, овцам, пензионерем) (БОГДАНОВИЋ, МАРКОВИЋ 2000: 160-161); ль као рефлекс слоготворног л иза $c$ и $\partial$; чување $л$ на крају слога (бил, а не бија); колективна множина (типа девојчетија); дативска енклитика женског рода вој (а не гу); акузативска енклитика женског рода jy (а не гу); енклитика акузатива множине личне заменице трећег лица $u$ (а не гu); заменица какво или кво уместо што; наставак $-y$, обично и -е у трећем лицу множине презента (а не -ејy/-ев, -ију/-ив); вокал у као континуант слоговног л иза велара (кук, кунем); вокал у као континуант слоговног л иза алвеопалатала (жут) (ИВИЋ 2009: 195-196). 
Иако смо навели готово све кључне особине сврљишко-заплањског дијалекта, како би се стекао комплетан увид у језички систем овог народног говора, приликом анализе романа Преображење фокусираћемо се само на фонетске одлике овог говора, у првом реду на чување полугласника, рефлекс јата, чување вокалног $л$, реализацију сонанта $j$, судбину сугласничке групе -хв-, статус сугласника $x$, чување африкате $s(\partial 3)$, судбину сугласника $\iota, \mu, \hbar, \hbar$, чување финалног л и јотовање.

\section{4. Вокалски систем сврљишко-заплањских говора}

„Вокали у српском књижевном језику уопште, а тако исто у главноме у овом дијалекту, представљају чисте звуке без специјалних нијанси” (БЕЛИЋ 1905: 13). Сврљишко-заплањски говори познају свих пет стандардних вокала $a, e, u, o, y$, полугласник ә и вокално $p$. Експираторни акценат, као и суседни гласови, утичу на вокале у правцу отворености, затворености или лабијализације (МАРКОВИЋ 2000: 27). Посебну пажњу заслужује стари вокал $л$ који у сврљишко-заплањском говору у роману Виолете Јовић доследно даје рефлекс лә.

\section{Полугласник}

Једну од најзначајнијих особина сврљишко-заплањског говора чини полугласник. „Њих има од две врсте: полугласници који се находе на оним местима на којима су се находили у нашем старом језику и такви који су се образовали у засебноме животу ових дијалеката, већином пред или за акцентом" (БЕЛИЋ 1999: 87). То значи да статус дијалеката не зависи само од њиховог „старог” места у језику, већ и од адаптације у различитим дијалектима. У роману Преображење има примера чувања старог полугласника у основи, у суфиксу, накнадно развијеног, у процесу девокализације и у речима страног порекла ${ }^{5}$. Ауторка је доследна у обележавању полугласника апострофом ${ }^{6}$ :

Спрам Петровд 'н ${ }^{7}$ баба ишла.... (3) ${ }^{8}$; не дочује б’u (3); ом'кне се (3); чујем да му жмичкају оп 'нuи (5); тек $m$ 'г загледа (5); шће јо с 'г и лавор

\footnotetext{
${ }^{5}$ Јордана Марковић у монографији Говор Заплања даје шире објашњење о критеријумима груписања ових примера (МАРКОВИЋ 2000).

${ }^{6}$ Ауторка изостављање гласова такође обележава апострофом.

${ }^{7}$ У говору Бучума и Белог Потока забележено је: благден, Велигден, Видовден, Бурђовден, Сnасовден и сл. (БОГДАНОВИЋ 1979: 10). С обзиром на то, можемо закључити да у овом случају употреба полугласника има стилску функцију, или се ради о говорнику или месту у којем се употребљава само облик са полугласником.

${ }^{8}$ Примери ће бити навођени према броју странице у роману.
} 
(8); m’г нареди (8); m’z се баба закашља (9); а c’г овој сас бабу (10); куде да се денем $m$ 'ح (11); c’н неће на очи (13); чим с'вну пролет (14); пријдо пол'к (14); прош'л комшија (15); како си разбрала да је б'ш дедин глас (16); па се уплашила да је дош'л (16); дан'с Петровд’н (17); дан'с Петровд 'н (17); башта ош'л по село (17); а с’г ћути (18); мати вели да је ош'л по село (29); дош'л сас чезе (33); твој башта дош'л (36); ош'л си (36); ожемо јеч'м (46); наскубе $р$ 'ж (46); на Прокоповд 'н смо в'зд'н врзували снопје (47); с’г бар л'сно (115); с'г бар л'сно (115); б’m ме брига за Милана (115); несу до с’г видели тој (116); не мог се м'кнем (117); на Спасовд 'н (120); дош'л Јованов брат (135); m'нка бела завеса од тил (149); слегне се за једну степеницу, а $m$ '2 тепих (150); од бел кон 'u (150); све се види, како по д’н (153); беле и црне д’чuще (154); $m$ 'нке дојду (154); $m$ ’ с седе на столичку (154), итд.

Полугласник се често јавља код показних заменица:

Oн'j из воденицу (3); ваљала се по он'j јаз (4); у ов 'j час (7); он'j јаст'к (8); он’j лавор (9); доб’p домазл'к (9); у m’j ма улеже башта (10); некол'ко кашичети од он'j чај (12); на он'j свет (15); у $m$ 'j ма (15); тури он 'j кот'л (15); на $о н$ 'j свет (16); а он 'j босиљак тури у недра (25); так'в ли ће ме чува (93); так'в ми не треба (93); чу чувам ов' дар (169); еве, ов'j моменат (169); ов'j ће златар да буде (210); стисал ме некак'в каракуш (210); так'в је ред (212); да ли је од ов’j назеб, ел сам се зарадувала (217), так'в је обичај (221) итд.

Под јаст 'к (7)9; још јед 'н јаст'к (8); још јед'н јаст 'к (8); он'ј јаст 'к (8); татко му једин'u̧ (27); Милена по јед’н (66); узе јед 'н кол'ц (67); мати донела на деду руч 'к (71); оћеш ли да напрајм по јед 'н сок (75); откину јед 'н тргоњ (76); четврт 'к беше (111); т'г све забори за јед'н час (123); јед’н цвет (133); само јед 'н (140); чича ни даде јед 'н транзистор (144); извади печено месо и јед’н петлиџан (145); у јед’н крај по цели зидови књиге (150); цел јед 'н зид (152); јед 'н голем шифоњер (152); сас јед 'н крај (152); у јед 'н голем куфер (167); на јед’н наређамо онија тањири (223).

Нес'м шњевала (15); нес'м (16); нес'м добра прилика (17); нес'м могла да дочекам (18); нес'м давала на Милана (19); нес'м ни осетила када (19); нес'м поштена девојка (21); више нес'м девојка како треба (22); нес'м јо рекла (23); нес'м била свесна (26); нес'м седела бађав (32); дош'л сас чезе (33); нес'м имала када (34); нес'м ни једно ни друго (35); нес 'м могал да спим (35); нес'м ни ја спала (35); толко рек'л (36); нес'м школувана (125); никада нес'м тој имала (131); ја нес'м прилика за теб (139); нес'м никад ни видела мушко без дреје (141); одавна нес'м такој добро спала (141); стварно нес'м (211); нес'м, бре, Веро (217) итд.

\footnotetext{
${ }^{9}$ У говорима Бучума и Белог Потока забележени су примери јестьк и јастьче (БОГДАНОВИЋ 1979: 9).
} 
Сл'нцее зашло одавна (3); очи му пуне сас сл'зе (10); сл'зе ми појдоше (11); кад Сл'ние поче заоди (34); сл'зе јо течу (52); сл'зе течу (55); сл'зе су ти за све (55); и сл'зе ни исти укус имају (55); обриса сл'зе (55); сјаји како сл'нцее (56); сл'ји повише од све (59); можда и оне нас виде како сл'јимо овде (59) итд.

Доб’р домазл'к (9); ни сас комиил'к не живувала (26).

Вокал $а$ на месту полугласника: отишла би бар на некол'ко дана (191), зашто ми после неси рекал (54) и сл.

Вокал е на месту полугласника:

за некол'ко дена (11); пројде десетину дена (46); за два-три дена (80); пројдоше некол'ко дена (111); не зна да сам вежбала некол'ко дена (157) и сл.

\section{Судбина вокала јат}

Рефлекс јата у призренско-тимочким дијалектима готово је доследно екавски, што важи и за сврљишко-заплањске говоре. У роману Преображење то се може пратити кроз читаво дело, а можда се најбоље уочава на примерима са одричним обликом глагола јесам:

Неје кадра (4); да неје наиш'л комшија (4); нес'м шњевала (15); нес'м (16); нес'м добра прилика (17); нес'м могла да дочекам (18); нес'м давала на Милана (19); нес' $м$ ни осетила када (19); нес'м поштена девојка (21); више нес 'м девојка како треба (22); нес'м јо рекла (23); нес'м била свесна (26); имање ни неје големо (26); неје ли нешто скршила (28); нес 'м седела бађав (32); нес 'м имала када (34); нес 'м ни једно ни друго (35); нес'м могал да спим (35); нес'м ни ја спала (35); прлега да неје (41); никад га нес'м шњевала (43); нес'м ни видела (43); ја нес'м поп (44); неје осења (44); Милана нес'м видела (46); несу Миланови (48); мора нес 'м ја (49); нес 'м га видела (50); нес 'м никад могла да замислим (50); слике никад неје (50); затој ми никад неси казала (52); нес 'м знала куде је (52); нес 'м га закопал ја (53); нес 'м ја (53); нес 'м тел да га узнем (53); зашто ми неси казал (53); зашто ми после неси рекал (54); зашто ми дете неси врнул (54); неси ти крив (54); ноћ нес'м састајил (54); мир нес'м имал (54); да ли је жива, ел неје (55); нес'м знала (56); око нес'м склопил (61); реч јо нес 'м поврнула (62); нес'м гладна (63); јоште неје жега (64); нес 'м мрднула из село (65); нес'м ни помислела на њег (65); нес'м ни погледала кол'ко снопје има (65); како да нес'м ни отодил (69); сливе нес'м видел (69); нес'м скоро иш'л до појату (69); нес'м скоро иш'л до појату (69); нес'м ју чула када се дигла (72); нес'м могла да замислим (74); нес'м њино дете (74); никад нес'м пробала нешто овакво (75); нес 'м знала (78); до с'г нес 'м (82); како и да несмо угасили 
светло (159); моји ме несу дали да идем више у школу (160); ми несмо имали млого књиге (160); несмо спали ни он ни ја (167); несмо били десетину дана (170); неси лоша (171); ми у село несмо имали обичај да чекамо Нову годину (181); како да неси родила (208); несу доодили откако се родило (212); никој се тој неје сетил (214); уплаши се да неси падла негде (216); несу ме тели за Милана (222) итд.

\section{Вокално $л$}

Рефлекс вокала л кључни је критеријум за поделу призренско-тимочких говора на три дијалекта. Он у овим говорима може имати рефлекс лә (сләнце ) и/или ла (сланц̧е) у сврљишко-заплањским, лу (слунцее) у призренско-јужноморавским, а овај вокал се чува у тимочко-лужничким говорима (слонце). Када је реч о сврљишко-заплањском дијалекту, Белић тврди да је вокално л „сасвим прешло у ль” (БЕЛИЋ 1905: 113). Н. Богдановић (1979: 15) бележи примере са лә за говор Белог Потока, који припада сврљишком типу сврљишко-заплањских говора. Такво стање може се уочити и на примерима из романа Преображење:

Сл'нце зашло одавна (3); очи му пуне сас сл'зе (10); сл'зе јо течу (52); сл'зе течу (55); сл'зе су ти за све (55); и сл'зе ни исти укус имају (55); обриса сл'зе (55); сјаји како сл'нце (56); сл'ји повише од све (59); можда и оне нас виде како сл'јимо овде (59); сл'нще изгрејује (61); сл'нще изгрејало (64); сл'нце високо беше (68); сас дл'ге косе (82); тек на Трновицу огреја Сл'нце (96); Сл'нце топрв изгрејује (108); појдоше ми сл'зе (119); па ми се набраше сл'зе у очи (121); мати брише сл'зе (132); појдоше сл'зе и мен (134); пробуди ме Сл'нце (141); појдоше ми сл'зе на очи (142); да пуштим и сл'зе да ми иду (169).

\section{5. Сугласници}

Сугласнички систем у роману Преображење садржи све сугласнике које има и стандардни српски језик, с тим што је њихова дистрибуција у неким примерима другачија од стандардног језика. За потребе овог рада издвојили смо карактеристике сонанта $j$, судбине групе $x в$, сугласника $x, s, \hbar, \hbar$, $\iota, \mu$, финалног $л$, фонетских промена као што су јотовање, палатализација, меатеза у сврљишко-заплањским говорима.

\section{Сонант $j$}

Сонант $j$ најпалаталнији је у нашем језику, што условљава његову изразито нестабилну артикулацији, о чему Н. Богдановић каже да „артикулација гласа $j$ варира у зависности од окружења у којем се налази, позиције у речи и акцента, затим од темпа говора, па и од говорних навика у једноме 
крају” (БОГДАНОВИЋ 1987: 94). Пол Луј Тома сматра да „реализације овога гласа иду од јасне прецизности до врло слабе чујности у којој је ометање проласка ваздушне струје мање јасно него између два вокала предњег реда у стд. реализацијама" (ТОМА 1998: 77). Губљење сугласника $j$ у роману забележено је у иницијалној и финалној позицији. Навешћемо неке примере:

Ел си жедна (14); ел си га видела (16); ел си ти, Милане, луд (35); ел си пијан (35); ел ти тебе, Милане, јасно (35); ел се уплашила (41); ел не скршила нешто (41); ел си га шњевала и пре (43); ел си гладна (63); ел ти добро (68); ел сте повиделе све по кућу (81); ел ти недобро нешто (85); ел је од неспање (85); ел ме не познаваш (87); ел баба нешто (89); ел доодила (89); ел не видиш да је брљива (114); ел сте ви нормални (127); ел сам ти убава (134); ел донел чаршав (142); ел била поштена (176); ел сте нормални ви (178); ел истин дошли (212); ел си за каву (212); ел ће остане да поседи малко (212); ел јо не доста јутрос што била (222); ел им носећа сна (223).

Учинило jo ${ }^{10}$ се (3); на ма' јо се учинило (3); марама јо се затрла (5); коса јо рачупена (5); тражи јо дреје за укоп (7); почиња да јо чука (7); докле јо најдем (7); шће јо с'г и лавор (8); па јо податури (8); на груди јо простр крпу (8); зима јо (8); ја јо суну (8); расплела јо косу (10); омимо јо и косу (12); облече јо чисте дреје (12); него јо само даде још некол'ко кашичети (12); мож јо притребају (12); мож јо се и слоша (12); жешка јо рука (14); нема сила да јо докажемо (16); да јо се учинило (16); назва јо божју помоћ (17); сна треба јо будем (17) итд.

Роман обилује примерима појаве секундарног $j$ у финалној позицији:

Који тој мож' да буде (3); нигде никој (3); баба се нагутала онуј блатњаву воду (4); кад видел да нема никој (4); сас оној на рамо (5); вода се цеди и од њег и од оној што носи (5); какво тој сецаш (5); тек т'г загледа оној (5); такој стоји (5); онуј бабу (6); на онуј (6); погано је тој (7); онеј суве дреје (7); од онуј каљаву воду (7); мен даде онуј шољу (8); mуj шољу (8); такој некол'ко пут (9); тој је добро (9); кој знаје (9); нек изврљи тој (9); несу тели да чују за тој (10); затој што сам сиротиња (10); а с'г овој сас бабу (10); и све такој (10); кој знаје (10); туј (11); такој остадоше (11); там у онуј недељу (11); мисли на тој (11); оној блато (12); туj, одма до њу (13); онај моја (13); ел си стоје туј (13); куде ми, туј и оне (13); онај моја (13); тој, вели, не ваља (14); видим да ју тој мучи (15); затој се свузала (16); ја туј ништа не могу (17); такој (19); седо на тој место (19); и такој (19); никој неће да знаје (20); нема ништа лоше у тој (20); mој је готова ствар (20); moj ме дозва у памет

\footnotetext{
${ }^{10}$ Овај и њему слични наведени примери односе се на личну заменицу женског рода она у дативу једнине.
} 
(21); на вр' оној брдо (21); поседе још малко такој (21); ми си знамо и никој више (22); оној чудо сас бабу (22); како тој да нема жељу да дојде (22); да дојде на овој место (22); после оној што се синоћ овде десило (22); тражила тој да јо спреми (23); седи такој (23); оној ћутање уз астал (23); ја си знам тој што знам (24); па се затој секирам (24); ел ће дојде туј (25); нема никој (25); туј малко постоја (25); кад видо оној место (26); с'г би ју, сас овеј штрокаве руке уватила за онуј белу косу (222); с'г би ју, сас овеј штрокаве руке уватила за онуј белу косу (222); пратила ју онај Душанка (222); а овеј опајдаре, дојде ми проз прозор да исврљим (222); зашто и онај његова мечка не остане (222); туј башта наместил големи астали (223); онеј бабе ји немаше (223); како такој зач'с (223); кој знаје да ли ће баба да поживи да га види (225); кој знаје кол'ко ће пројде (225); ете, такој сваки д’н ме задева (225) итд.

Ретки су примери појаве протетичког гласа $j$ : скину им јулари (80).

$$
\text { Судбина групе -хв- }
$$

На месту групе хв у говорима Бучума и Белог Потока најчешће се јавља в: вала ти, уватило, а понекад ф: фала, фала богу (БОГДАНОВИЋ 1979: 33).

У роману је забележено стање које потврђује чешћу употребу в $<x в$. Малобројни су примери са $\phi<x в$ :

Богу фала (18); фала ти, Боже (52); тебе само могу да зафалим (54); фала ти, Веро (54); Боже, фала ти (56).

Знатно су бројнији примери у којима је $в<x в$ од основе $x в а m-$ :

само што се увати за кваку (4); она завати (8); да заватим воду (17); завата воду (17); завати си воду (17); нешто ме уватило (18); докле се довати до сливак (34); па ме довати (37); како овцу кад увате (37); он се увати за оној уво (38); мен да довати (38); уватеше ме за руку (40); ал ме мати увати за руку (42); да се уватим за њег (42); с'н ме увати (47); привати им ствари (50); да заватимо воду (56); чича ни увати за руке (58); уватимо се за руке (59); уватимо се за руке (61); да завати ладну водицу (65); сви туј заватају воду (65); завата воду (67); завати воду (67); завати воду (68); да заватим воду (71); увати се за једну сливу (76) итд.

\section{Сугласник х}

Фонолошки систем сврљишко-заплањских говора не познаје фонему $x$ (уп. БОГДАНОВИЋ 1979: 28), због чега је карактеристично њено губљење из свих позиција: иницијалне, медијалне и финалне:

А како оди (5); ладна како змија (6); ајде малко чај да пинеш (8); несу тели (10); ладан зној (11); оће ме узне (11); оће нешто да рекне (14); 
оћеш ли нешто (14); оди овам (14); мора да оће нешто (14); тела да утекне (16); Врљи леба на мачке (17); куде оћемо (18); имамо време кол'ко оћемо (20); оди овам (20); ако оће још малко да узне (24); да узне лебаи (24); одим пол'к (25); оће ли ти душица нешто (29); оће изеду све вунено (31); фала ти, Боже (166); ћу вревим какво oћy (175); е, oћy (175); ако ти неће слушаш, село оће (177); тек ће се он за главу вата (178); добро је што оће још да се школује (180); она ми не дава ништа да радим, а ја oћy, па оћу (181); оће да је уз мене (184); оћеш да ми помогнеш (187); oћy заједно да одлучимо (200); ajде у кућу (208); како сас квас'ц да те ране (209); оћеш ли да улегнеш (212); оће ли да поседе неки д'н (212); јоште не оди (213); ајде овам у кућу (216); шта има да се ради, ајде (216); оћеш ли на немачки (221); несу ме тели за Милана (223); ајде, бре, бабо (224) итд.

Кад проодила (3); нетеја ју питујем (8); Свети Ранђел (9); да не дооде јутре (10); нетејаше искоче (11); нетејаше да чују (11); нетеја ништа (12); нетеја да ју тера (12); видел те како проодищ (16); порани пилићи (17); греота да такој заврши (26); она само узд'ну (30); нетеја да разврзујем онија бошчалуци (31); кад Сл'нце поче заоди (34); да од'нем малко (35); дооди сваки ч'с (42); ти знаш твоји греови (44); нетеја да пије каву (45); узд'ну дубоко (45); мати га нетеја ни погледа (52); докле ми ти не опростиш греови (62); не опраштам ја греови (63); први пут овде прооди (64); погледам ју на маови (66) итд.

На $м a^{\prime}$ јо се учинило (3); ја идо (4); чу како тропну (4); не стиго (5); докле донесо (7); ја изнесо (7); докле се ја врну (8); jа јо суну (8); уврљи неколко корењиша (9); на вр тури једно дрво (9); на вр тури једно дрво, да држи огањ (9); седо на троношку пред шпорет (9); седо на троношку пред шпорет, па се замисле (9); у т'ј ма (10); добро те не закла прасе (10); некакво ми се само слеже у стомак, туј, одма подгруди (11); устресо се (11); ото да си легам (12); пробра једну и залледа се у њу (13); туј одма до њу друга једна (13); најдо кревет у мрак и седо на сламњачу (13); лего си (13); облеко се и намести кревет (14); пожури да видим да ли је баба жива (14); улего у кујну (14); погледа кам бабин кревет (14); Погледа у матер. Не смем да питам ништа (14); пријдо пол'к до бабин кревет (14); узе ју за руку (14); у т'ј ма (15); од некакву жилу се па соплето (16); упадо у јаз (16); ја ју разбра (16); излего из собу (17); узе тестије па појдо на кладанац (17); појдо на кладанац да заватим воду (17); стра ме да однесем дете у село (205); од њег одма пресече овуј муку (217); стра ме ако неки познаје да личи на Милана (219); пита ји какво ново има у њи (223) итд. 


\section{Африката $s$ (дз)}

Африката $s$ (дз) чува се у сврљишко-заплањским говорима као једна од карактеристика овога дијалекта (в. БОГДАНОВИЋ 1979: 34), али и свих призренско-тимочких говора. Ауторка африкату $s$ доследно обележава као дз:

Одзебла (8); мати се удзрла у њу (15); идем си по пут, а све се обдзртам (23); нес'м имала када ни задзирам (34); па јо се задзр (42); па ју задзр (45); па се задзр у прсти (68); задзира узокол по њиве (69); стану над бабу, па ју задзрта (82); реши да се не вртам, нити да се обдзртам (87); чекам и обдзртам се (106); Милан се удзрл узам (113); што ми сви редом надзртају међу ноге (194); мора сам одзебла (210).

\section{Сугласници $\iota, \mu, \hbar, \hbar$}

Све поменуте африкате познате су у сврљишко-заплањским говорима и доследно се чувају, односно постоје оба пара стандардне артикулације. Међутим, једна специфичност коју проналазимо у роману јесте у вези са императивом старих атематских глагола: Виђ какво иска (62); виђте који је тој $(220)^{11}$. Ради се о архаичним облицима императива који су задржали форме са јотованим сугласником.

\section{Финално л}

Познато је да судбина финалног $л$ није у свим говорима призренскотимочког говорног подручја иста, али ,у већем делу говора ове зоне сачувано је незамењено -л на крају слога, односно речи" (ИВИЋ 1985: 111-112), што је случај и у сврљишко-заплањском дијалекту. Појаву потврђује стање у говорима Бучума и Белог Потока (БОГДАНОВИЋ 1979: 17, 85). Појаву можемо пратити на примерима анализираног романа, у којима се финално $л$ чува у именицама, придевима, у радном глаголском придеву мушког рода једнине и у прилозима:

Напунила кот'л (8); носи кот 'л сас млеко (15); тури он'ј кот'л (15); проз тај мисал (19); како пет'л од кокошку (21); из т'ј мисал (40); оној што Ђавол растаља (58); па ни одведе до астал (58); поседамо уз астал (58); прлега да има неки ђавол у реку (82); как’в Ђавол (82);

Јучер сам цуел д’н чистила (31); цел век (38); цел д’н (41); кисел (76); свекров и свекрвин гроб бел (163); види се озгор цчел Београд (164); он весел, сија (165);

Вода била слаба, мора да је јоште неки пред њу, уз реку, навађувал (3); вртал се човек од косидбу (4); чул бабу (4) врлил косу и цедило од рамо

\footnotetext{
${ }^{11}$ Потврде иве појаве налазимо у говору Белог Потока: јеђ, јеђи, јеђте, виђ, виђте, док је у Бучуму: јеи, вии, јечте, вичте (БОГДАНОВИЋ 1979: 85).
} 
(4); урипил и он у јаз (4); он се уплашил, па ју вукал, дрмал (4); окал човек (4); кад видел да нема никој (4); косу и цедило заборил на ливаду (4); какво си се укипил (6); Бог те убил (6); дал ти Бог (6); једва ји је Милан умолил (10); видим да је ровал (10); да би ми рекал нешто (10); и да ме питал (10); једва ји је убедил (11); нешто што си одавна затрл (49); мислел да ће испадне бољ муж (114); тел је, можда, поскупо да се продаде (114); кад би ме с'г остајил овде и отиш'л, не знам како би сама (168); кад би ме с'г остајил овде и отиш'л, не знам како би сама (168);

Там окол Преображење (11); готви некакво окол шпорет (14); готви окол шпорет (17); мати окол шпорет (27); башта се замајал окол говеду (34) итд.

Ћу дим у понеделник (33); преко селску орницу (65); кам Долюу Дубраву (66); туј, из дольу малу (77); поделбина, кућа им до кућу (83); у долюу малу (86); чују се свирачи у дольу малу (109); туј има једно асталче (150); на њег ниско асталче (150); Поделбина (211); Јован ради у понеделник (212).

\section{Јотовање}

У роману Преображење има примера јотованих облика. У раду ће бити представљени примери одступања од старог, новог и специјалног јотовања као и примери аналошког јотовања.

\section{Одступање од старог јотовања}

Говори призренско-тимочког дијалекта разликују се од стандардног језика по томе што су у њима потрвени резултати старог јотовања (БОГДАНОВИЋ, МАРКОВИЋ 2000: 64) и таквих примера има у роману:

одомени (74); нема ништа сломено (81); потопена у чашу воду (142).

\section{Одступање од новог јотовања}

Ново јотовање последица је губљења полугласника у слабом положају. У говорима Бучума и Белог Потока углавном нема резултата новог јотовања (БОГДАНОВИЋ 1979: 38-39). У роману има примера који потврђују одступање од ове гласовне алтернације:

Да му палиш свећу за здравје (15); изврзамо и сноnje (46); на Прокоповд'н смо в'зд'н врзували снопje (47); запали свећице за здравје (61); да зденемо оној снопје (63); снопје легло по њиву (65); нес'м ни погледала кол'ко сноnjе има (65); приносимо сноnje (66); а кам ли снопје (66); трава у снопје зелена (66); сас башту и сас чичу товарили cнопjе (96); донела сам ти семе од дивјо зеље (220).

Забележен је и пример ширења резултата јотовања: на крај попушти (103). 


\section{Одступање од специјалног јотовања}

Карактеристика сврљишко-заплањских говора јесте одсупање од тзв. специјалног јотовања где се група јд код глагола сложених од ити не јотује (в. БОГДАНОВИЋ 1979: 38). То доказују и примери из романа:

Појде си баба (3); да дојде да му помогне (4); пројдоше ме жмарци (5); докле јо најдем (7); па си појде (9); да најдем косу (9); треба да дојдy (9); да дојду јутре (10); сл’зе ми појдоше (11); има да дојду (11); најдо кревет (13); пријдо пол'к (14); пријде до нас (15); појдо на кладанац (17); дојде ми жал (17); појдо уз пут (18); кад си појдо дома (18); жмарци ме пројдоше (19); да дојду да питују за мен (19); дојде ми да се укачим (21); добро би било да дојде (22); стра ме да нешто не појде наопако (22); појдо дома (23); дојду некако суре (23); ако нешто појде како не треба (24); ел ће дојде туј (25); појдо по врвину (25); кад пројдо код воденицу (25); па си појдо (25); појдо си уз реку (26); дојде двапут потешка (28); да ли ће кноћи да дојде у сливак (30); башта и чича ће дојду сас говеду да отерају дом (116); појдоше ми сл'зе (119); спрам свадбу сам му пратила писмо, да дојде да му рекнем (120); дојде ми да рипнем однегде (122); обиђе астал, па дојде до мен (122); пријдо до њег (124); пријдо до њег (124); Милена пријде до нас (127); кад дојде, ми ће му дадемо (213); кад најду некога другога (216); напривечер дојде комшија Милород (220); ја га сварим и попијем и оно одма пројде (220); овеј опајдаре дојде ми проз прозор да исврљим (222); не осетим кад си прејдем на нашки (224); ће дојду напролет (225); кој знаје кол'ко ће пројде (225) итд.

\section{Аналошко јотовање}

Примери извршеног јотовања према аналогији су малобројни:

Вежени пешкири (31); конци за вежење (31) ${ }^{12}$.

\section{Палатализација}

Овде се неће јавити тзв. лужничка палатализација, где се палатализује

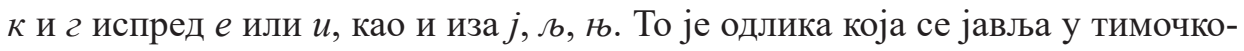
лужничким говорима, по чему се разликују сврљишко-заплањски говори. Н. Богдановић је потврде извршене лужничке палатализације забележио у говору Бучума, али не и у говору Белог Потока који припада сврљишком-заплањском дијалекту (БОГДАНОВИЋ 1979: 39), Међутим, и овде ће се јавити аналошко уопштавање резултата палатализације као што је забележено у примерима: сл'зе јо течу (52); сл'зе течу (55) ${ }^{13}$.

\footnotetext{
${ }^{12}$ Сличне примере налазимо у БОГДАНОВИЋ 1979: 37.

${ }^{13}$ Овакве потврде забележене су и у Бучуму и Белом Потоку (БОГДАНОВИЋ 1979: 41).
} 
Метатеза

Под појмом метатезе подразумева се промена места појединих гласова или читавих слогова у речима. У роману Преображење ово није честа појава: по лојза (18); јутре до пладне (20); прошло пладне (30); одма ми с 'вну у главу $(77)^{14}$.

\section{6. Закључак}

На основу разматраних примера из грађе може се закључити да фонетске особине језика романа Преображење Виолете Јовић углавном одговарају сврљишко-заплањском дијалекту.

Вокалски систем познаје пет стандардних вокала $a, e, u, o, y$, вокално $p$ и полугласник, који ауторка обележава апострофом.

Поред примера у којима се полугласник чува ( $\partial$ 'н, с’2, рек'л, нес'м...), уочила сам и примере где се, уместо полугласника налази неки од вокала (ден, суза).

Замена јата у овом роману готово је доследно екавска, што одговара једној од основних карактеристика призренско-тимочких говора, па и сврљишко-заплањског дијалекта, а што се може пратити кроз читаво дело.

Вокално л има један рефлекс - лд, који је једна од основних карактеристика сврљишко-заплањског говора, а који ауторка обележава са л', нпр. сл'за, сл'ние.

Када је реч о сугласницима, специфично је то што сугласник $x$ такође има веома нестабилну артикулацију с обзиром на то да се губи и у иницијалној (ајде, аљину, оћу, ране, ладно ), у медијалној (греови, довати) и у финалној позицији (постоја, донесо, њи, би).

Изостају специјално јотовање (дојде), као и ново јотовање у одређеним категоријама (сноnje), а нарушени су и резултати старог јотовања (одомен).

На основу обрађене грађе, може се закључити да фонетски дијалектизми у роману Преображење у великој мери одговарају сврљишкозаплањском дијалекту, осим у оном делу романа који је писан стандардним језиком, а који се односи на говор лекара и других ликова који припадају урбаној средини. То нам говори о језичкој карактеризацији ликова и њиховом обликовању тако да се дијалекат приписује говорницима руралне средине, односно необразованим говорницима, а да је стандардни језик својствен образованом становништву, односно припадницима урбане средине. Међутим, у овом роману главна јунакиња доживљава својеврсни преображај, не само у духовном смислу, већ и у језичком. Стицањем образовања, културним и духовним уздизањем, јунакиња је све више одбацивала дијалекатски, а усвајала стандардни језички тип. Оно што је занимљиво јесте да се, са по-

\footnotetext{
${ }^{14}$ Тако и код Н. Богдановића (1979: 47).
} 
вратком у руралну средину, главна јунакиња враћа своме дијалекту. То значи да је он оставио дубок траг у њеној психолошкој слици и да је он јунакињи иманентан. На основу тога може се извући имплицитна порука ауторке да је стандардни језик вештачка творевина и да је он, као такав, наметнут човеку, те да се треба служити дијалектом, као „природним” језичким обликом. Такав закључак ишчитава се и из интервјуа са ауторком.

Још једна занимљивост јесте недоследност у обележавању изостављеног вокала. То се може протумачити као ауторкина „игра” са читаоцима ради постизања што већег степена експресивности, или, пак, као несвесно урањање ауторке из света реалности у свет књижевног дела, при чему она запоставља своју ауторску (корективну) функцију и поистовећује се са својим јунацима попримајући њихове језичке особине. С друге стране, можемо претпоставити да то може бити и реална слика развоја дијалекта у којем се постепено губе изворна обележја, што свакако бива и са полугласником.

\section{Цитирана литература}

БЕЛИЋ, Александар. Дијалекти источне и јужне Србије, Српски дијалектолошки зборник, I, Српска краљевска академија, Београд, 1905.

БОГДАНОВИЋ, Недељко. Говори Бучума и белог Потока. Српски дијалектолошки зборник, XXV, Институт за српскохрватски језик, Београд, 1979.

БОГДАНОВИЋ, Недељко, Јордана Марковић. Практикум из дијалектологије. Ниш: Филозофски факултет, 2000.

БОГДАНОВИЋ, Недељко. Говор Алексиначког Поморавља. Српски дијалектолошки зборник, ХХХІІІ, Институт за српскохрватски језик, САНУ, Београд, 1987.

ИВИЋ, Павле. Дијалектологија српскохрватског језика. Увод и штокавско наречје. Друго издање, Нови Сад: Матица Српска, 1985.

ИВИЋ, Павле. Српски дијалекти и юихова класификација. Сремски Карловци, Нови Сад: Издавачка књижарница Зорана Стојановића, 2009.

МАРКОВИЋ, Јордана. Говор Заплања. Српски дијалектолошки зборник XLVII, Институт за српски језик САНУ, Српска академија наука и уметности, Београд, 2000.

ТОМА, Пол Луј. Говори Ниша и околних села. Ниш: Просвета, 1998.

$$
\text { Извор }
$$

ЈОВИЋ, Виолета. Преображење. Ниш: Медивест, 2011. 
Sara N. Nemat

\section{PHONETIC DIALECTISMS AS A CHARACTERISTIC OF VIOLETA JOVIĆ'S LITERARY ART STYLE IN THE NOVEL PREOBRAŽENJE}

The subject of this paper is the examination of the features of phonetic dialectisms on the example of the novel Preobraženje by Violeta Jovic with a review of the literary and artistic features of the work. This paper will aim to analyze the linguistic features of the Svrljig-Zaplanje dialect and to determine possible deviations about them. Also, it will be shown how the characterization of the characters and the motivation of the work were performed through the dialect.

Keywords: serbian language, dialects, Svrljig-Zaplanje dialect, Prizren-Timok dialect area, novel, Preobraženje, Violeta Jović. 